\title{
KADAR NaCl DAN KADAR PROTEIN TELUR ASIN BERDASARKAN LAMA PENGERAMAN
}

\author{
Nur Qadri Rasyid ${ }^{1)}$ Anita $^{1)}$, Feri $^{1)}$ \\ 1)Akademi Analis Kesehatan Muhammadiyah Makassar
}

\begin{abstract}
Abstrak
Telur adalah salah satu pangan sumber protein yang banyak diminati oleh masyarakat karena memiliki rasa yang lezat mudah dicerna, bergizi tinggi, mudah diperoleh dan memiliki harga yang murah. Namun, telur segar mempunyai batas waktu penyimpanan yang singkat, oleh sebab itu perlu diawetkan dengan cara pengasinan. Telur asin merupakan telur yang diawetkan dengan cara penggaraman agar membuang rasa amis dan menciptakan rasa yang khas. Saat perendaman akan terjadi penambahan konsentrasi garam pada bagian dalam putih dan kuning telur sehingga mempengaruhi tekstur, warna, aroma dan rasa. Di sisi lain, penambahan konsentrasi garam pada putih telur dapat mengakibatkan terjadinya denaturasi protein yang akan menurunkan kadar protein dalam telur. Penelitian ini bertujuan untuk mengetahui hubungan kadar $\mathrm{NaCl}$ dan kadar protein telur asin berdasarkan lama pengeraman 0, 4, 9 dan 14 hari yang dianalisis dengan metode mohr untuk menentukan kadar $\mathrm{NaCl}$ dan metode kjeldahl untuk menganalisis kadar protein. Hasil penelitian menunjukkan terjadi penurunan kadar protein selama penyimpanan, sementara kadar kadar $\mathrm{NaCl}$ mengalami peningkatan. Kadar $\mathrm{NaCl}$ pada 0, 4, 9 dan 14 hari berturut-turut adalah 14.59\%, 44.19\%, 57.25 \%, 63.29\%, kemudian kadar protein telur asin pada 0, 4, 9 dan 14 hari berturut-turut adalah 15.00\%, 12.92\%, 11.08\%, dan 8.38\%. Berdasarkan dari hasil penelitian ini dapat disimpulkan bahwa peningkatan konsentrasi $\mathrm{NaCl}$ berdasarkan lama pengeraman dapat menurunkan kadar protein.
\end{abstract}

Kata Kunci: Kadar NaCl, Protein, Telur asin, Lama pengeraman

\section{PENDAHULUAN}

Telur merupakan sumber protein yang memberikan sumbangan terbesar bagi tercapainya kecukupan gizi masyarakat. Sebutir telur didapatkan gizi yang cukup sempurna karena mengandung protein cukup tinggi dengan susunan asam-asam amino lengkap, mengandung lemak tak jenuh, vitamin, dan mineral untuk memenuhi kebutuhan tubuh (Sudaryani, 2003).

Pasokan telur sekarang ini masih belum mampu mencukupi permintaan konsumen karena tindakan pascapanen yang dilakukan kurang baik, hal ini disebabkan banyaknya telur yang rusak atau busuk karea penyimpanan, suhu ruang penyimpanan, kelembaban ruang penyimpanan, kotoran yang ada pada kulit telur, teknik penanganan telur, dan peralatan yang digunakan dalam memperpanjang masa simpan telur (Riskesda, 2007). penanganan. Oleh karena itu, tindakan pengawetan telur dilakukan agar telur dapat bertahan lebih lama. Selain itu, nilai ekonomis telur awetan lebih tinggi daripada telur mentah (Haryadi, 2014).

Telur yang sering dikonsumsi masyarakat adalah telur itik dan telur ayam. Namun karena baunya yag amis, telur itik jarang digunakan dibandingkan telur ayam. Sebagai usaha untuk menghilangkan bau yang amis tersebut telur itik diolah menjadi telur asin, hal ini memungkinkan karena pori-pori telur itik lebih besar dibandingkan telur ayam. Telur asin merupakan telur yang diawetkan dengan cara pengeraman. Tujuan utama dari proses pengasinan telur yaitu untuk membuang rasa amis dan menciptakan rasayang khas serta untuk

Komponen utama dalam pembuatan telur asin selain telur itik 
adalah garam. Garam adalah seasoning dan pengawet yang komposisinya terdiri atas natrium klorida $(\mathrm{NaCl})$ (Prihantoro, 2003). Garam berfungsi untuk merangsang cita rasa dan sebagai pengawet bahan pangan alami. Semakin tinggi kadar garam yang diberikan dalam poses pengasinan telur maka semakin meningkatkan daya simpannya (Saliem HP et al., 2001). Menurut ahli gizi, garam $\mathrm{NaCl}$ tidak baik dikonsumsi oleh penderita tekanan darah tinggi (hipertensi). Sehingga disarankan bagi penderita tekanan darah tinggi untuk mengurangi konsumsi makanan yang mengandung $\mathrm{NaCl}$. Selain itu, penambahan garam yang terlalu tinggi juga dapat mengakibatkan terjadinya denaturasi protein pada putih telur disebabkan adanya gangguang atau perubahan pada struktur sekunder dan tersier akibat terjadinya interaksi dengan garam (Purwoko T, 2009). Hal tersebut dikuatkan dengan pernyataan Winarno (2002) yang mengatakan bahwa bila dalam suatu larutan protein ditambahkan garam, daya larut protein akan berkurang, akibatnya protein akan terpisah sebagai endapan.

Peningkatan garam $\mathrm{NaCl}$ dapat meningkatkan terjadinya denaturasi protein telur. Penelitian ini bertujuan untuk mengetahui kadar $\mathrm{NaCl}$ dan kadar protein telur asin berdasarkan lama pengeraman.

\section{METODE PENELITIAN}

\section{Alat dan Bahan}

Peralatan yang digunakan dalam proses penelitian ini adalah mortar dan timbangan, labu ukur, erlenmeyer, buret, statis, pipet tetes, penangas air, lemari asam, gelas ukur, gelas piala dan neraca analitik, pipet volume, penangas air, bulp, evaporator, labu penampung, labu kjeldahl, labu destilasi, dan separatory funnel.

Bahan yang digunakan untuk membuat sampel adalah: telur itik yang memenuhi syarat (1) Warna cangkang terang dan cerah (2) Cangkang telur tidak retak atau pecah (3) Tidak berbau busuk dan titrasi dengan $\mathrm{AgNO}_{3}$ 0,1 N perlahanlahan sampai terjadi warna merah bata,
(4) Telur bersih dari kotoran fisik, abu gosok, garam dapur, dan air secukupnya. Bahan yang digunakan untuk analisis kadar garam $\mathrm{NaCl}$ dan kadar protein adalah $\mathrm{AgNO}_{3} \quad 0,1 \quad \mathrm{~N}, \mathrm{~K}_{2} \mathrm{CrO}_{4} \quad 5 \%$ dan aquadest, selenium mix, $\mathrm{H}_{2} \mathrm{SO}_{4}$ pekat, batu didih,aquadest, $\mathrm{NaOH} 40 \%$, larutan asam borat $35 \%$, indikator PP, indikator mengsel, dan $\mathrm{HCl}$ standar.

\section{Prosedur Penelitian}

\section{Persiapan Sampel}

a. Cara membuat telur asin :

Telur itik dicuci dengan air bersih, kemudian dibuat balutan dari abu gosok dan garam dengan perbandingan $1: 1,5$ kemudian dituang sedikit demi sedikit air sampai adonan bisa dikepal, setiap butir telur dibalut dengan adonan bulatan setebal $\pm 0,5 \mathrm{~cm}$, setelah telur selesai dibalut, telur disimpan selama, 4, 9, dan 14 hari pada tempat yang bersih dan kering.

b. Cara penyimpanan :

Adapun cara penyimpanan telur asin adalah sebagai berikut: Periode penyimpanan untuk masing-masing sampel adalah 4, 9 dan 14 hari, setiap akhir periode penyimpanan dilakukan pencucian kemudian dilakukan perebusan c. Perebusan:

Proses perebusan bertujan untuk mematangkan telur asin, proses ini dilakukan pada panci. Setelah proses perebusan dilakukan pengujian kadar garam dan protein pada sampel telur asin

\section{Penetapan Kadar $\mathrm{NaCl}$}

Prosedur penetapan kadar $\mathrm{NaCl}$ menggunakan metode mohr : menyiapkan alat dan bahan yang akan digunakan, membilas buret dengan aquadest kemudian kalibrasi dengan AgNO3, mengisi buret dengan AgNO3 0,1 N, timbang sampel yang telah dihaluskan sebanyak 5 gram, sampel di ekstraksi (disaring) dengan penambahan $10-20 \mathrm{ml}$ aquadest panas dan ditunggu selama beberapa menit sehinggah semua garam $\mathrm{NaCl}$ larut semua, cairan ekstrak ditampung dalam wadah dan dicampur dengan baik, cairan yang diperoleh kemudian ditambahkan $3 \mathrm{ml} \mathrm{K}_{2} \mathrm{CrO}_{4} 5 \%$ 
hasil yang diperoleh kemudian dimasukkan dalam persamaan matematis berikut :

$\% \mathrm{NaCl}$

$$
=\frac{\mathrm{V} \mathrm{AgNO3} \times \mathrm{N} \mathrm{AgNO3} \times \mathrm{Mm} \mathrm{NaCl} \times \mathrm{FP}}{\mathrm{mg} \text { sampel }} x
$$

Keterangan :

$\mathrm{V}$ : Volume $\mathrm{AgNO}_{3}$ yang digunakan dalam

titrasi

$\mathrm{N}:$ Normalitas $\mathrm{AgNO}_{3}$

FP : Faktor Pengenceran

Mm : Massa Molar

\section{Penetapan Kadar Protein Metode Kjeldhal}

Menimbang sampel dengan teliti sebanyak 2 gr, sampel dimasukkan kedalam labu kjeldhal $100 \mathrm{ml}$, menambahkan 1 gr campuran seleniuym mix dan $10 \mathrm{ml} \mathrm{H}_{2} \mathrm{SO}_{4}$ pekat, kemudian didestruksi diruang asam, mula mula dengan suhu kecil dan membesar secara bertahap sampai dihasilkan larutan jernih kuning, biarkan dingin kemudian tuang kedalam labu ukur $100 \mathrm{ml}$ dan bilas dengan air suling dan ditempatkan sampai tanda tera labu ukur, disiapkan penampungan yang terdiri dari $10 \mathrm{ml}$ $\mathrm{H}_{3} \mathrm{BO}_{3} 2 \%$ dan 4 tetes indikator Mengsel (indikator $\mathrm{MM}+\mathrm{MB}$ ), dimasukkan kedalam labu destilasi, tambahkan indikator PP dan $\mathrm{NaOH} 30 \%$ kedalam 2 ml larutan sampel sedikit demi sedikit dengan menggunakan pipet tetes (sampai warna berubah menjadi merah) dan 100 $\mathrm{ml}$ air suling, suling hingga volume penampungan menjadi lebih kurang 50 ml, kemudian titrasi dengan larutan $\mathrm{H}_{2} \mathrm{SO}_{4} 0,0142 \mathrm{~N}$ yang telah distandarisasi, hasil yang diperoleh kemudian dimasukkan dalam persamaan matematis : $\%$ Protein $=\% \mathrm{~N} \times$ Faktor konversi

Faktor konversi $=6,25$

$\% \mathrm{~N}=$

$\frac{\text { T.sampel 1-T.Balanko x N H2SO4 x } 14 \text { x FP }}{\text { mg Sampel }} \times 100 \%$

\section{HASIL PENELITIAN}

Penelitian ini menggunakan metode eksperimen dengan analisa laboratorium menggunakan telur asin. Pembuatan telur asin dilakukan dengan membalut telur menggunakan adonan abu gosok, setelah telur selesai dibalut, telur disimpan selama, 4, 9, dan 14 hari pada tempat yang bersih dan kering. Analisis kadar $\mathrm{NaCl}$ dan kadar protein pada telur diperiksa sebelum mengalami perlakuan dan setelah mengalami perlakuan di 4, 9 dan 14 hari. Hasil Analis kadar $\mathrm{NaCl}$ dan Kadar Protein yang diperoleh pada telur asin tertera pada tabel 1 .

Tabel 1. Kadar $\mathrm{NaCl}$ dan kadar protein telur asin berdasarkan lama pengeraman

\begin{tabular}{ccc}
\hline Lama & $\%$ & $\%$ \\
Pengeraman & $\mathrm{NaCl}$ & Protein \\
\hline $\mathbf{0}$ & 14.58 & 15.00 \\
$\mathbf{4}$ & 44.19 & 12.92 \\
$\mathbf{9}$ & 57.25 & 11.08 \\
$\mathbf{1 4}$ & 63.29 & 8.39 \\
\hline
\end{tabular}

Hasil analisis kadar $\mathrm{NaCl}$ dan kadar protein pada telur asin berdasarkan lama pengeraman $0,4,9$ dan 14 hari menunjukkan terjadinya peningkatan kadar NaCl. Sebelum mengalami perlakuan, kadar garam $\mathrm{NaCl}$ pada telur itik sebesar $14.58 \%$ dan setelah diberi perlakuan kadar $\mathrm{NaCl}$ meningkatan selama masa simpan hingga $63.29 \%$. Sementara hasil analisis kadar protein mengalami penurunan selama masa pengeraman. Sebelum diberi perlakuan kadar protein pada telur itik sebesar 15.00 $\%$ dan setelah mengalami perlakuan menurun hinga kadar protein yang tersisa sebesar $8.39 \%$.

\section{PEMBAHASAN}

Dalam proses pengasinan telur dibalut dengan campuran abu gosok dan garam yang selanjutnya disimpan selama beberapa hari hingga garam yang melekat pada kulit telur dapat berdifusi ke dalam telur melalui pori-pori kulit telur. Penambahan garam dalam proses pengawetan telur memberikan pengaruh yang nyata terhadap penurunan kandungan protein. Hasil analisis menunjukkan tingginya konsentrasi $\mathrm{NaCl}$ pada telur asin berpengaruh terhadap penurunan kandungan protein pada telur asin Gambar 1 menunjukkan Selama 
proses pengeraman hingga 14 hari konsentrasi $\mathrm{NaCl}$ pada telur asin meningkat hingga $76.96 \%$. sedangkan kandungan protein mengalami penurunan hingga $44.07 \%$.

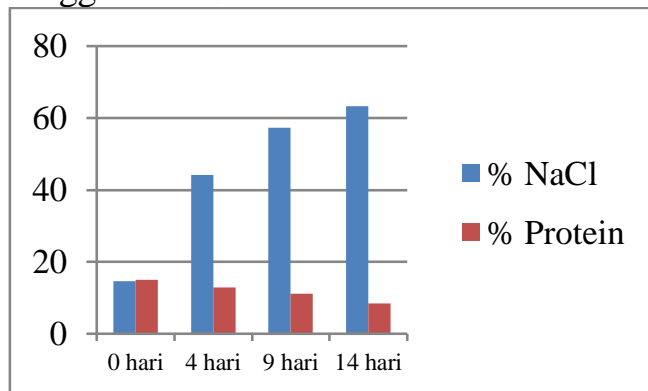

Gambar 1. Grafik persentasi kadar $\mathrm{NaCl}$ dan kadar protein pada telur asin berdasarkan lama pengeraman.

Penurunan kandungan protein selama proses pengasinan sebanding dengan lamanya proses penyimpanan. Selama masa penyimpanan garam akan berpenetrasi secara sempurna melewati kulit telur sehingga protein telur akan mengalami denaturasi. Denaturasi terjadi karena protein ditambahkan dengan garam maka daya larut protein akan berkurang. Sehingga menyebabkan protein akan terpisah menjadi endapan atau yang disebut sebagai salting out (Winarno, 1997).

Pada hari ke-14 proses pengasinan, kandungan protein telur asin bersisa 8.39\% kadar ini sudah tidak memenuhi standar kadar protein yang disarankan oleh WHO (1999) yaitu sebesar 10-15\% protein untuk memenuhi konsumsi energi makanan sehari (Almatsier, 2002), maka telur asin yang dierami hingga hari ke-14 tersebut tidak layak dikonsumsi untuk memelihara kesehatan yang baik. Oleh sebab itu penambahan garam secara berlebih dan lamanya penyimpanan pada proses pembuatan telur asin dapat menyebabkan terjadinya denaturasi. Denaturasi terjadi karena terjadinya perubahan pada struktur tersier dan sekunder protein yang umumnya mengalami presipitasi dan koagulasi protein (Lehninger, 2005). Hal ini sejalan dengan yang dikemukakan Astri (2008) bahwa semakin lama umur simpan telur maka akan menyebabkan putih telur menjadi lebih encer, sehingga mengakibatkan larutan garam mudah masuk ke dalam telur pada saat pengasinan. Semakin banyak jumlah garam $\mathrm{NaCl}$ yang berpenetrasi akan menentukan rasa asin telur serta kemasiran kuning telur dan sebanding dengan tingkat denaturasi yang terjadi. Selain itu, penelitian yang dilakukan oleh Amir et al (2014) juga menunjukkan terjadi penurunan kadar protein untuk tiap-tiap formula selama proses pengolahan dan masa penyimpanan, sementra kadar garam $\mathrm{NaCl}$ mengalami peningkatan. Denaturasi protein tertinggi terjadi pada masa simpan 7 hari, pada Formula A sebesar 25,58\%, Formula B $30,62 \%$, dan Formula C 28,04\%. Sementara peningkatan tertinggi pada kadar garam $\mathrm{NaCl}$ juga terjadi pada hari ketujuh, hasil analisis pada Formula A menunjukkan hasil sebesar 2,51\%, pada Formula B dan Formula $\mathrm{C}$ berturut-turut $2,55 \%$ dan $2,93 \%$.

Beberapa penelitian ini menunjukkan bahwa konsentrasi garam $\mathrm{NaCl}$ berpengaruh terhadap denaturasi protein pada telur asin yang dapat menyebabkan terjadinya penurunan kandungan protein.

\section{KESIMPULAN DAN SARAN}

Berdasarkan hasil penelitian mengenai Kadar $\mathrm{NaCl}$ Dan Kadar Protein Telur Asin Berdasarkan Lama Pengeraman dapat disimpulkan bahwa lama pengeraman akan berpengaruh terhadap peningkatan konsentrasi $\mathrm{NaCl}$ dan berpengaruh terhadap penurunan kadar protein telur asin.

Disarankan bagi peneliti hendaknya melakukan uji organoleptik untuk mengetahui tingkat kesukaan konsumen terhadap kadar $\mathrm{NaCl}$ telur asin.

\section{DAFTAR PUSTAKA}

Astri D, 2008. Sifat Fisik, Kimia dan Organoleptik Telur Asin yang Direndam pada Konsentrasi Garam dan Umur Telur yang Berbeda. Institut Pertanian Bogor, Bogor. 
Amir S. Sirajuddin S. Jafar N. 2014. Pengaruh Konsentrasi Garam Dan Lama Penyimpanan Terhadap Kandungan Protein Dan Kadar Garam Telur Asin. Universitas Hasanuddin, Makassar

Almatsier S, 2002. Prinsip Dasar Ilmu Gizi. Penerbit PT Gramedia Pustaka Utama, Jakarta.

Badan Penelitian dan Pengembangan Kesehatan. Riset Kesehatan Dasar

Saliem HP, EM.Lakolo,T.B. Purwantini, M. Ariani dan Y. Marisa, 2001. Analisis Ketahanan Pangan Tingkat Rumah Tangga dan Regional [Laporan Hasil Penelitian].

Sudaryani, T. 2003. Kualitas Telur. Penebar Swadaya, Jakarta.
(Riskesdas), 2007. Kementrian Kesehatan Republik Indonesia, Jakarta

Haryadi. 2014. Cara Sukses Memulai dan Menjalankan Usaha Ternak Itik, Trans Idea Publishing, Jogjakarta. Lehninger, Thenawijaya Maggie, 2005. Dasar-Dasar Biokimia. Jilid 2. Ciracas, Jakarta.

Purwoko T, 2009. Fisiologi Mikroba. Bumi Aksara, Jakarta .

Winarno FG, S, Koswara. 2002. Telur : Komposisi, Penanganan dan Pengolahannya. M-Brio Press, Bogor.

Winarno FG, 1997. Kimia Pangan dan Gizi. PT. Gramedia Pustaka Utama,

Jakarta. 